\title{
Production of benzoic acid as a natural compound in fermented skim milk using commercial cheese starter
}

\author{
Sun-Young Park, ${ }^{*}$ Mi-Young Yoo, ${ }^{*}$ Hyun-Dong Paik, $†$ and Sang-Dong Lim*1 \\ *Korea Food Research Institute, Seongnam 13539, Korea \\ †Division of Animal Life Science, Konkuk University, Seoul 05029, Korea
}

\begin{abstract}
In this study, we investigated the production of natural benzoic acid (BA) in skim milk fermentation by 5 kinds of commercial cheese starters. Five kinds of starter were inoculated into $10 \%$ reconstituted skim milk, and then the culture was incubated at 2-h intervals for $10 \mathrm{~h}$ at 30,35 , and $40^{\circ} \mathrm{C}$. In fermentation by MW $046 \mathrm{~N}+\mathrm{LH} 13$, the starter for making raclette, BA was highly detected after $8 \mathrm{~h}$ at 30 and $35^{\circ} \mathrm{C}$. In fermentation by LH 13, the starter for making berg, BA steadily increased and was highly detected at $40^{\circ} \mathrm{C}$. In fermentation by TCC-3+TCC-4, the starter for making Caciocavallo and mozzarella, BA was detected after 2 $\mathrm{h}$ at $40^{\circ} \mathrm{C}$. Also, BA was detected after 4 and $8 \mathrm{~h}$ at 35 and $30^{\circ} \mathrm{C}$, respectively. In fermentation by Flora-Danica, the starter for making Gouda, BA was increased until $6 \mathrm{~h}$ and decreased after $6 \mathrm{~h}$ at all temperatures. Among the 5 kinds of fermentation, the level of BA was the highest in fermentation by Flora-Danica at $6 \mathrm{~h}$ at $35^{\circ} \mathrm{C}$, at $14.55 \mathrm{mg} / \mathrm{kg}$.
\end{abstract}

Key words: benzoic acid, cheese starter, skim milk, fermentation

\section{INTRODUCTION}

Benzoic acid is widely used in the food industry as a food preservative. Characterized by effective antibacterial properties (Daeschel, 1997), it has antimicrobial activity against an extensive range of bacteria, yeasts, and molds involved in food intoxication and food spoilage (Chipley, 1993). Several studies have demonstrated that benzoic acid effectively inhibits pathogens such as Listeria monocytogenes (El-Shenawy and Marth, 1988), Aspergillus (Rusul and Marth, 1988), Vibrio sp.

Received December 5, 2016

Accepted February 20, 2017.

${ }^{1}$ Corresponding author: limsd@kfri.re.kr
(Beuchat, 1980), Escherichia coli (Splittstoesser et al., 1996), and Penicillium sp. (Thompson, 1997).

According to the US Food and Drug Administration, benzoic acid and its potassium and sodium salts are regarded as generally recognized as safe (Boer and Nielsen, 1995). Although benzoic acid is extensively used in food and it is generally recognized as safe, several adverse effects, such as metabolic acidosis, asthma, urticaria, hyperpnoea, and convulsions, were observed in experimental animals and humans given very high doses of benzoic acid. For these reasons, the use of benzoic acid as food additives is limited by specific regulations in different countries (Tfouni and Toledo, 2002). The Joint FAO/WHO Expert Committee on Food Additives (WHO, 2000) has evaluated and established an acceptable daily intake for benzoic acid, benzoate salt, benzaldehyde, benzyl acetate, and benzyl alcohol of 0 to $5 \mathrm{mg} / \mathrm{kg}$ of BW.

However, even if not added as a food preservative, benzoic acid also occurs naturally in several foods and commodities, such as fruits, vegetables, spices, and nuts, and also in dairy products at low concentrations (Nagayama et al., 1983, 1986; Heimhuber and Hermann, 1990). Sieber et al. (1995) analyzed and surveyed natural occurrence of benzoic acid in various types of cultured dairy products and cheeses. Those authors found that benzoic acid appears to be generated as a by-product of the microbial degradation of either hippuric acid or phenylalanine in these products. Also, oxidation of benzaldehyde produced by certain strains of lactic acid bacteria may generate benzoic acid. The production of several organic acids, including benzoic acid, could depend on fermentation starters and conditions (González de Llano et al., 1996; Mroueh et al., 2008).

The objective of our study was to investigative the change of natural benzoic acid produced from fermentation using 5 commercial cheese starter cultures (TCC-3, TCC-4, LH 13, MW 043 N, and Flora-Danica) at different temperature for establishment of the allowable level of naturally produced benzoic acid in cheese. 
Table 1. Commercial starters and their strains used in cheese manufacture

\begin{tabular}{lll}
\hline Starter $^{1}$ & Strains & Cheese \\
\hline TCC-3 & Lactobacillus delbrueckii ssp. bulgaricus & Caciocavallo, \\
+ & + & mozzarella \\
TCC-4 ${ }^{2}$ & Lactobacillus delbrueckii ssp. bulgaricus & \\
& Streptococcus thermophilus & Berg \\
LH 13 & Lactobacillus helveticus & Raclette \\
MW $046 \mathrm{~N}$ & Lactococcus lactis ssp. cremoris & \\
+ & Lactococcus lactis ssp. lactis & \\
LH $13^{3}$ & Lactococcus lactis ssp. diacetylactis & \\
& Leuconostoc mensenteriodes ssp. cremoris & \\
& + & \\
Flora-Danica & Lactobacillus helveticus & Gouda \\
& Lactococcus lactis ssp. cremoris & \\
& Lactococcus lactis ssp. lactis & \\
& Lactococcus lactis ssp. diacetylactis & \\
\hline
\end{tabular}

${ }^{1} \mathrm{MW} 046$ N, LH 13, TCC-3, TCC-4 (Sacco, Cadorago, Italy), and Flora-Danica (Chr. Hansen, Hørshølm, Denmark).

${ }^{2}$ TCC-3 and TCC-4 were mixed in the ratio 1:1.

${ }^{3} \mathrm{MW} 046 \mathrm{~N}$ and $\mathrm{LH} 13$ were mixed in the ratio 7:3.

\section{MATERIALS AND METHODS}

\section{Cheese Starters}

Five commercial, freeze-dried direct vat set cheese starters, MW 046 N, LH 13, TCC-3, TCC-4 (Sacco, Cadorago, Italy), and Flora-Danica (Chr. Hansen, Hørsholm, Denmark), were used. Mixing proportions of starter for making cheese were those used in commercial production. Mixing proportions and strains are given in Table 1.

\section{Growth of Strain}

The count of viable starter strains was determined by serial 10 -fold dilution in $0.1 \%$ peptone water. About $10^{5} \mathrm{cfu} / \mathrm{mL}$ of starter was inoculated into $10 \%$ reconstituted skim milk, and then the culture was incubated at 2 -h intervals for $10 \mathrm{~h}$ at 30,35 , and $40^{\circ} \mathrm{C}$. All pour plates were incubated aerobically at $37^{\circ} \mathrm{C}$ for $48 \mathrm{~h}$ using a bromo cresol-purple (BCP) plate count agar (Eiken, Tochigi, Japan)

\section{pH and Acidity}

The $\mathrm{pH}$ was measured using $\mathrm{pH}$ meter (Inolab 7110 $\mathrm{pH}$ BNC, WTW, Weilheim, Germany). For measuring acidity, $9 \mathrm{~mL}$ of sample was diluted with $18 \mathrm{~mL}$ of distilled water. Next, $0.5 \mathrm{~mL}$ of $1 \%$ phenolphthalein solution was added and the solution was titrated by $0.1 \mathrm{~N} \mathrm{NaOH}$ solution until it became pink for $30 \mathrm{~s}$. The acidity was determined using the following formula:

$$
\begin{aligned}
\text { Acidity }(\%)= & {[\text { titration amount of } 0.1 \mathrm{~N} \mathrm{NaOH}(\mathrm{mL})} \\
& \times 0.009 / \text { sample }(\mathrm{g})] \times 100 .
\end{aligned}
$$

\section{HPLC-Photodiode Array Analysis of Benzoic Acid Contents}

Standard and Chemicals. A commercial standard (Sigma Aldrich, St. Louis, MO) of benzoic acid was used. We purchased HPLC-grade solvents from J.T. Baker (Phillipsburg, NJ), and other reagents (analytical grade) were purchased from Wako (Tokyo, Japan).

Sample Preparation. Sample preparation was conducted in accordance with Korean Food Additives Codex (MFDS, 2014). Five grams of cheese sample was accurately weighed and distilled water added to a total volume of $50 \mathrm{~mL}$. The sample was vortexed for $1 \mathrm{~min}$, sonicated for $20 \mathrm{~min}$, and then filtered. Five milliliters of filtrate was mixed with $1.5 \mathrm{~mL}$ of $0.1 \mathrm{~N} \mathrm{HCl}$ and $0.5 \mathrm{~mL}$ of $0.005 \mathrm{M}$ cetyltrimethylammonium chloride solution.

Sep-Pak C18 cartridges (Waters Associates, Milford, MA) were prepared before use by successively washing each cartridge with $10 \mathrm{~mL}$ of methanol and $10 \mathrm{~mL}$ of $0.005 M$ cetyltrimethylammonium chloride solution; the mixed solution was applied to the Sep-Pak cartridge at a flow rate of $2 \mathrm{~mL} / \mathrm{min}$. After washing with 10 $\mathrm{mL}$ of water, the solution was eluted with $10 \mathrm{~mL}$ of methanol. The solution was filtered through a $0.45-\mu \mathrm{m}$ filter paper.

HPLC-Photodiode Array Analysis. An HPLC with a photodiode array (Shiseido. Co. Ltd., Tokyo, 
Table 2. The linearity and sensitivity data of benzoic acid

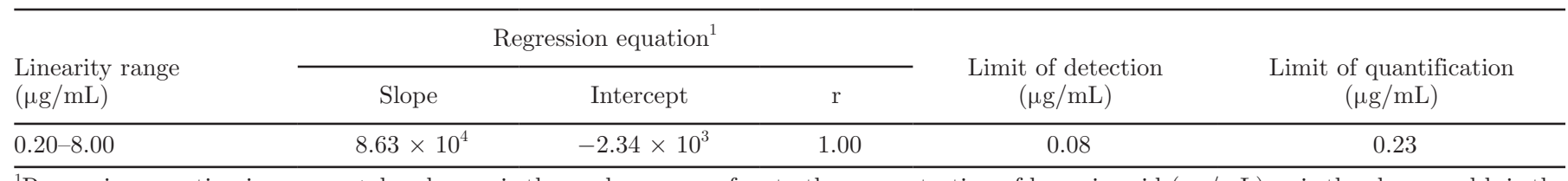

${ }^{1}$ Regression equation is $\mathrm{y}=a \mathrm{x}+\mathrm{b}$, where $\mathrm{y}$ is the peak area, $\mathrm{x}$ refers to the concentration of benzoic acid $(\mu \mathrm{g} / \mathrm{mL}), a$ is the slope, and $\mathrm{b}$ is the intercept.

Japan) analysis of benzoic acid concentration was conducted in accordance with Korean Food Additives Codex (MFDS, 2014). The operating conditions were column temperature, $35{ }^{\circ} \mathrm{C}$; flow rate, $1.0 \mathrm{~mL} / \mathrm{min}$; injection volume, $10 \mu \mathrm{L}$; and photodiode array detection at $217 \mathrm{~nm}$. The maximum extinction wavelength of benzoic acid was $230 \mathrm{~nm}$. Chromatographic separations were performed on an $\mathrm{SP}^{\wedge}$ Column MF C8 (5.0 $\mu \mathrm{m}$ particle size, $150 \times 4.6 \mathrm{~mm}$ i. d.; Shiseido Co. Ltd.), and the mobile phase consisted of $0.1 \%$ tetrabutylammonium hydroxide (phase A) and $100 \%$ acetonitrile (phase $\mathrm{B}$ ). The following gradient was applied: 0 to $2.5 \mathrm{~min}$, $25 \% \mathrm{~B} ; 2.5$ to $7.0 \mathrm{~min}, 25$ to $35 \% \mathrm{~B} ; 7.0$ to $12.0 \mathrm{~min}, 35$ to $40 \% \mathrm{~B} ; 12.0$ to $15.0 \mathrm{~min}, 40$ to $30 \% \mathrm{~B}$.

\section{Validation Procedures}

To validate the benzoic acid analysis method, we determined the limit of detection (LOD), limit of quantification (LOQ), linearity, repeatability, and accuracy. The LOD and LOQ were calculated according to the following equations (Miller and Miller, 1988):

$$
\begin{gathered}
\mathrm{LOD}=3.3 S_{a} / b, \text { and } \\
\mathrm{LOQ}=10 S_{a} / b,
\end{gathered}
$$

where $S_{a}$ is the standard deviation of the intercept and $b$ is the slope of the regression line obtained from the calibration. Standard solutions were prepared at 1.0, 2.0 , and $4.0 \mu \mathrm{g} / \mathrm{mL}$ of benzoic acid. After the preconditioning process, recovery was determined by HPLC analysis.

\section{Statistical Analysis}

The results are expressed as the mean \pm standard deviation. Statistical analysis was performed with SAS software (version 9.0, SAS Institute Inc., Cary, NC). The significance of the differences was analyzed by conducting a one-way ANOVA with Duncan's multiple range tests. Values of $P<0.05$ were considered statistically significant.

\section{RESULTS AND DISCUSSION}

\section{Method Validation}

The linearity and sensitivity data of natural food preservatives are given in Table 2 . The linearity range for benzoic acid was 0.2 to $8.0 \mu \mathrm{g} / \mathrm{mL}$, and the linear regression curve showed a correlation coefficient $>0.99$. The LOD and LOQ values for benzoic acid were 0.08 and $0.23 \mu \mathrm{g} / \mathrm{mL}$, respectively.

Precision and accuracy data for the determination of benzoic acid are given in Table 3. The experiments of repeatability and recovery have been performed on 3 different days with the same instrument but different operators. Repeatability values calculated as result dispersion in terms of standard deviation (RSD). Recovery data were calculated by comparing the concentration of spiked cheese samples and determined by interpolation on the calibration curve with the nominal fortification level. The intraday RSD for benzoic acid were 1.82 to 4.02, and the interday RSD for benzoic acid were 1.97 to $3.19 \%$. For method validation, intra- and interday RSD must be $\leq 15 \%$ at all quality control and dilution control concentrations (Pereira et al., 2000). In our experiment, all RSD were less than $15 \%$. Recovery values for benzoic acid were 95.35 to $99.83 \%$. Compared with the international level of recovery value of 80 to $120 \%$, the recovery values in the test were good.

\section{Benzoic Acid Content}

We investigated the changes in the numbers of viable bacteria, benzoic acid content, $\mathrm{pH}$, and acidity in skim milk fermented by 4 mixed cheese starter cultures. Changes in $\mathrm{pH}$ and acidity are shown in Table 4, and starter culture growth curves and production of benzoic acid are shown in Figure 1.

The TCC-3 and TCC-4 mixture, used for production of Caciocavallo cheese, was inoculated into $10 \%$ reconstituted skim milk and the culture was incubated at 2 -h intervals for $10 \mathrm{~h}$ at 30,35 , and $40^{\circ} \mathrm{C}$. The growth of lactic acid bacteria increased sharply at 35 and $40^{\circ} \mathrm{C}$, and $\mathrm{pH}$ sharply decreased at $40^{\circ} \mathrm{C}$. It seems 
Table 3. The precision and accuracy data for the determination of benzoic acid in spiked cheese ${ }^{1}$

\begin{tabular}{|c|c|c|c|c|}
\hline $\begin{array}{l}\text { Spiked concentration } \\
(\mu \mathrm{g} / \mathrm{mL})\end{array}$ & $\begin{array}{l}\text { Detected concentration } \\
(\mu \mathrm{g} / \mathrm{mL})\end{array}$ & $\begin{array}{l}\text { Recovery } \\
(\%)\end{array}$ & $\begin{array}{c}\text { Intraday test } \\
\left(\mathrm{n}=3, \mathrm{RSD} \%^{2}\right)\end{array}$ & $\begin{array}{l}\text { Interday test } \\
(\mathrm{n}=9, \mathrm{RSD} \%)\end{array}$ \\
\hline 4.00 & $3.81 \pm 0.08$ & $95.35 \pm 1.99$ & 2.09 & 3.19 \\
\hline 2.00 & $1.97 \pm 0.04$ & $98.60 \pm 1.79$ & 1.82 & 1.97 \\
\hline 1.00 & $1.00 \pm 0.04$ & $99.83 \pm 3.99$ & 4.02 & 2.66 \\
\hline
\end{tabular}

${ }^{1}$ Values are shown as the mean \pm standard deviation of triplicate.

${ }^{2} \mathrm{RSD}=$ result dispersion of $\mathrm{SD}$

as if Streptococcus thermophilus, one of the lactic acid bacteria in TCC-4 starter, led to the overall growth of bacteria because the optimum temperature of the strain is $40^{\circ} \mathrm{C}$ (Beal et al., 1989). Benzoic acid was highly produced at $40^{\circ} \mathrm{C}$ until $8 \mathrm{~h}$ of incubation, and it was more highly produced at $35^{\circ} \mathrm{C}$ after $10 \mathrm{~h}$ of incubation. During fermentation, the growth of lactic acid bacteria reached up to $9.19 \log \mathrm{cfu} / \mathrm{mL}$, and the highest benzoic acid content was $2.38 \mathrm{mg} / \mathrm{kg}$ (Figure 1a). In a previous study, benzoic acid content of Caciocavallo cheese produced by TCC-3 and TCC-4 starter was $1.66 \mathrm{mg} /$ kg (Park et al., 2016).

The growth of lactic acid bacteria in skim milk fermented by LH 13 starter, used for production of berg cheese, increased sharply at $40^{\circ} \mathrm{C}$ and $\mathrm{pH}$ sharply decreased at $40^{\circ} \mathrm{C}$. Benzoic acid production gradually increased at all temperatures from 2 to $6 \mathrm{~h}$. It increased rapidly at $40^{\circ} \mathrm{C}$ after $8 \mathrm{~h}$ and at $35^{\circ} \mathrm{C}$ after $10 \mathrm{~h}$. The growth of LH 13 starter strain reached $8.94 \log \mathrm{cfu} / \mathrm{mL}$, and benzoic acid content reached $13.88 \mathrm{mg} / \mathrm{kg}$ (Figure 1b).

The growth of lactic acid bacteria in skim milk fermented by the MW $046 \mathrm{~N}$ and LH 13 mixture, used for production of raclette cheese, was similar at all 3 temperatures studied. The $\mathrm{pH}$ was also similar, but it decreased quickly at $35^{\circ} \mathrm{C}$. The highest count of viable bacteria was $9.11 \log \mathrm{cfu} / \mathrm{mL}$ at $40^{\circ} \mathrm{C}$ after $10 \mathrm{~h}$. Production of benzoic acid rapidly increased at 30 and $35^{\circ} \mathrm{C}$ after $8 \mathrm{~h}$. The benzoic acid content was 0 to 10.49 $\mathrm{mg} / \mathrm{kg}$ (Figure 1c).

The growth of lactic acid bacteria in skim milk fermented by Flora-Danica starter, used for production of Gouda cheese, was similar at all 3 temperatures until 6 $\mathrm{h}$ and the most increased at $40^{\circ} \mathrm{C}$ after $6 \mathrm{~h}$. After $10 \mathrm{~h}$ of incubation at $40^{\circ} \mathrm{C}$, the starter strain count was 9.22 $\log \mathrm{cfu} / \mathrm{mL}$. The change in $\mathrm{pH}$ tended to be similar

Table 4. Change of $\mathrm{pH}$ and acidity of fermented skim milk by commercial cheese starter

\begin{tabular}{|c|c|c|c|c|c|c|c|c|}
\hline Starter $^{1}$ & Item & $\begin{array}{l}\text { Incubation } \\
\text { temperature }\left({ }^{\circ} \mathrm{C}\right)\end{array}$ & \multicolumn{6}{|c|}{ Incubation time $(\mathrm{h})$} \\
\hline TCC-3 & $\mathrm{pH}$ & 30 & 6.52 & 6.5 & 6.47 & 6.37 & 6.03 & 5.57 \\
\hline \multirow[t]{3}{*}{ TCC-4 (1:1) } & & 40 & 6.52 & 6.32 & 6.11 & 5.3 & 4.67 & 4.51 \\
\hline & Acidity & 30 & 0.18 & 0.18 & 0.18 & 0.19 & 0.25 & 0.49 \\
\hline & $(\%)$ & 35 & 0.18 & 0.18 & 0.18 & 0.25 & 0.45 & 0.61 \\
\hline \multirow{4}{*}{ LH 13} & & 40 & 6.38 & 6.35 & 6.3 & 6.11 & 5.5 & 4.65 \\
\hline & Acidity & 30 & 0.18 & 0.18 & 0.19 & 0.20 & 0.20 & 0.25 \\
\hline & $(\%)$ & 35 & 0.18 & 0.18 & 0.18 & 0.19 & 0.23 & 0.32 \\
\hline & & 40 & 0.18 & 0.18 & 0.19 & 0.23 & 0.41 & 0.68 \\
\hline \multirow{2}{*}{$\begin{array}{l}\text { MW } 046 \text { N } \\
\quad+ \\
\text { LH } 13(7: 3)\end{array}$} & $\mathrm{pH}$ & 30 & 6.38 & 6.36 & 6.35 & 6.27 & 5.91 & 5.28 \\
\hline & & 35 & 6.38 & 6.36 & 6.34 & 6.25 & 5.76 & 4.84 \\
\hline \multirow{5}{*}{ Flora-Danica } & & 35 & 6.35 & 6.3 & 6.17 & 5.86 & 5.17 & 4.79 \\
\hline & & 40 & 6.35 & 6.29 & 6.22 & 6.11 & 5.06 & 4.73 \\
\hline & Acidity & 30 & 0.18 & 0.19 & 0.20 & 0.26 & 0.45 & 0.49 \\
\hline & $(\%)$ & 35 & 0.18 & 0.19 & 0.21 & 0.27 & 0.47 & 0.67 \\
\hline & & 40 & 0.18 & 0.20 & 0.20 & 0.25 & 0.49 & 0.68 \\
\hline
\end{tabular}

${ }^{1}$ MW 046 N, LH 13, TCC-3, TCC-4 (Sacco, Cadorago, Italy), and Flora-Danica (Chr. Hansen, Hørsholm, Denmark). 


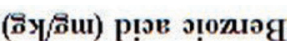
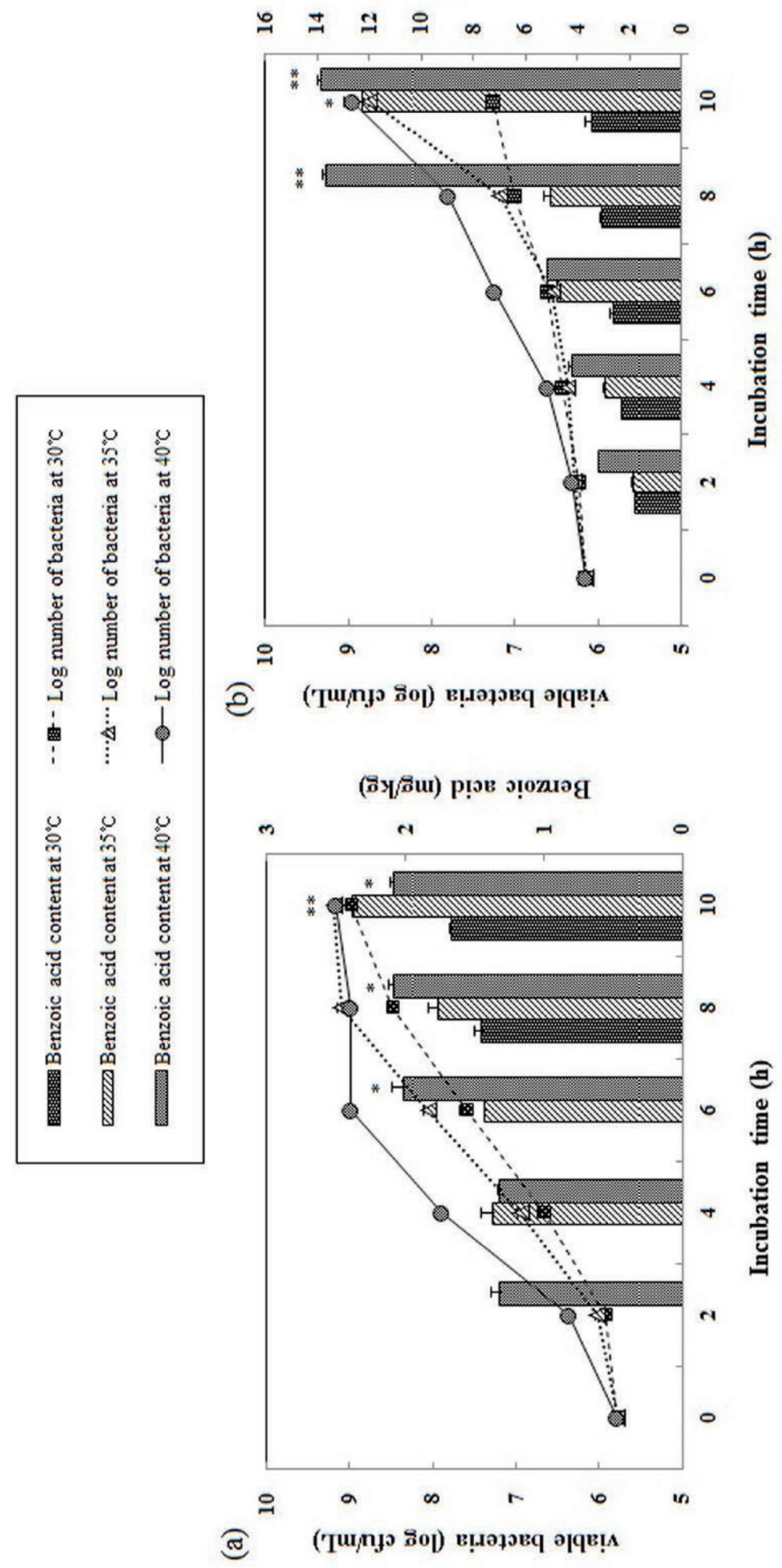

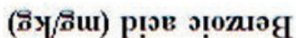

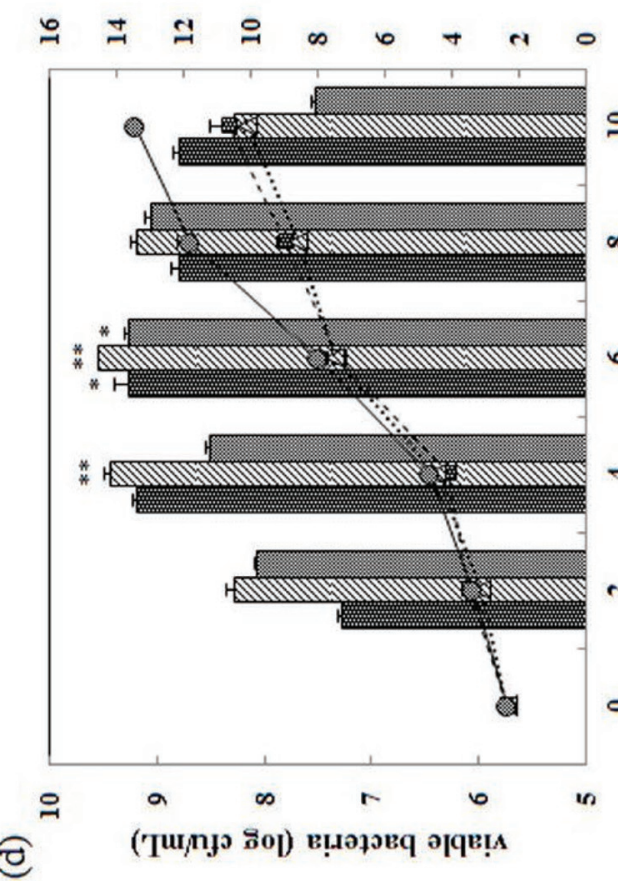

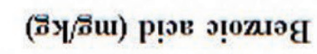

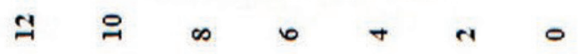

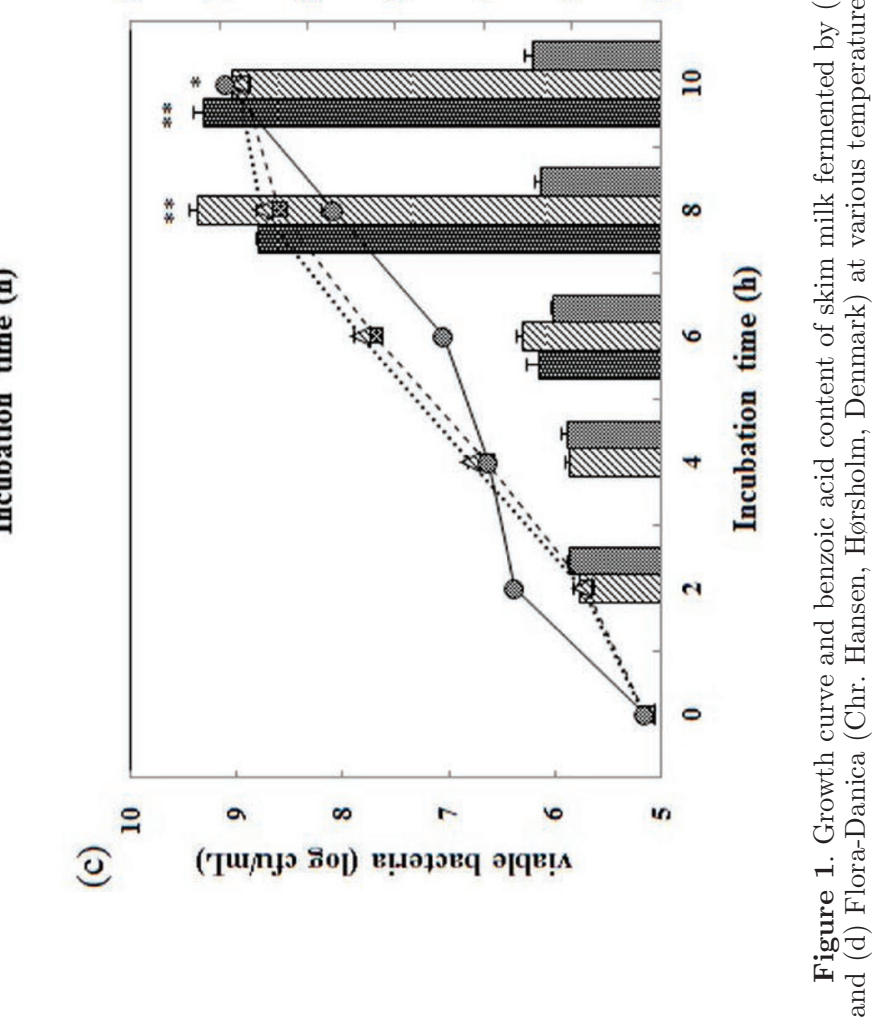

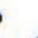


to that of the growth curve. Benzoic acid production began at $2 \mathrm{~h}$, increased until $6 \mathrm{~h}$, and decreased thereafter. Benzoic acid was highly produced at $35^{\circ} \mathrm{C}$, with content ranging from 0 to $14.55 \mathrm{mg} / \mathrm{kg}$ (Figure 1d). In a previous study, benzoic acid contents of berg, raclette, and Gouda cheese produced by the cheese starters used in the current study were 2.91, 2.12, and $3.61 \mathrm{mg} / \mathrm{kg}$, respectively (Park et al., 2016).

Benzoic acid was not detected at $0 \mathrm{~h}$ in any culture and was only detectable after $2 \mathrm{~h}$ of incubation in some cultures, suggesting that benzoic acid content was associated with the growth of lactic acid bacteria. When cheese starter cultures were incubated, the decline in free AA concentration was dependent on $\mathrm{pH}$, and the optimum pH was about 6.0 (Tavaria et al., 2002). Under these conditions, lactic acid bacteria convert free AA such as hippuric acid, naturally present in milk, to benzoic acid (Nishimoto et al., 1968, 1969; Horak et al., 1996). In our study, benzoic acid was mostly produced when the $\mathrm{pH}$ was about 6.0. In particular, the benzoic acid content in skim milk fermented by Flora-Danica starter was the highest when the $\mathrm{pH}$ was about 6.0 and decreased at lower $\mathrm{pH}$ values.

In the study of Urbiene and Leskauskaite (2006), pasteurized milk was fermented by 3 different commercial dairy starters at $32^{\circ} \mathrm{C}$ for $7 \mathrm{~h}$, and benzoic acid content in fermented milk was 14 to $23 \mathrm{mg} / \mathrm{kg}$. The formation of benzoic acid in fermented milk depended on the phase of the development of lactic acid bacteria and was most intensive in the log phase, which could be seen in our results. Benzoic acid was more abundantly and rapidly produced at the optimum growth temperature of strains in starter. The highest benzoic acid content during fermentation by the 4 mixed starter cultures ranged from 2.38 to $14.55 \mathrm{mg} / \mathrm{kg}$.

\section{CONCLUSIONS}

This study aimed to investigate the change of naturally occurring benzoic acid during skim milk fermentation by 5 commercial cheese starters (MW $046 \mathrm{~N}$, LH 13, TCC-3, TCC-4, and Flora-Danica). The amounts of benzoic acid in fermented skim milk were influenced by the starter culture. Benzoic acid during fermentation by the TCC- 3 and TCC- 4 mixture was produced at a high rate at $40^{\circ} \mathrm{C}$ until $8 \mathrm{~h}$ of incubation and was produced at a high rate at $35^{\circ} \mathrm{C}$ in $10 \mathrm{~h}$ of incubation. During fermentation, lactic acid bacteria reached counts of $9.19 \log \mathrm{cfu} / \mathrm{mL}$, and the highest benzoic acid content was $2.38 \mathrm{mg} / \mathrm{kg}$. In LH 13 fermentation, the production of benzoic acid increased at $40^{\circ} \mathrm{C}$ up to $13.88 \mathrm{mg} / \mathrm{kg}$. For fermentation by the MW $046 \mathrm{~N}$ and LH 13 mixture, benzoic acid rapidly increased at 30 and $35^{\circ} \mathrm{C}$ after $8 \mathrm{~h}$ in a concentration range of 0 to $10.49 \mathrm{mg} / \mathrm{kg}$. Benzoic acid was produced during Flora-Danica fermentation after $2 \mathrm{~h}$, increased until $6 \mathrm{~h}$, and decreased after 6 h. Overall, benzoic acid was highly produced at $35^{\circ} \mathrm{C}$. Benzoic acid was naturally produced and the amounts produced differed depending on incubation time, temperature, and starter strain. The results of our study could be applied to the establishment of the permission standard for benzoic acid in cheese products.

\section{ACKNOWLEDGMENTS}

This research was supported by a grant (14162MFDS087) from the Ministry of Food and Drug Safety (Osong, Korea) in 2014.

\section{REFERENCES}

Beal, C., P. Louvet, and G. Corrieu. 1989. Influence of controlled pH and temperature on the growth and acidification of pure cultures of Streptococcus thermophilus 404 and Lactobacillus bulgaricus 398. Appl. Microbiol. Biotechnol. 32:148-154.

Beuchat, L. R. 1980. Comparison of anti-Vibrio activities of potassium sorbate, sodium benzoate, and glycerol and sucrose esters of fatty acids. Appl. Environ. Microbiol. 39:1178-1182.

Boer, E., and P. V. Nielsen. 1995. Food preservatives. Pages 289-294 in Introduction to Food-Borne Fungi. R. A. Samson, E. S. Hoekstra, J. C. Frisvad, and O. Filtenborg, ed. Centraalbureau Voor Schimmelcultures, Utrecht, the Netherlands.

Chipley, J. R. 1993. Sodium benzoate and benzoic acid. Pages 11-48 in Antimicrobials in Foods. 2nd ed. P. M. Davidson and A. L. Branen, ed. Marcel Dekker, New York, NY.

Daeschel, M. S. 1997. Antimicrobial substance from lactic acid bacteria for use as food preservatives. Food Technol. 1:164-167.

El-Shenawy, M. A., and E. H. Marth. 1988. Inhibition and inactivation of Listeria monocytogenes by sorbic acid. J. Food Prot. 11:842-847.

González de Llano, D., A. Rodriguez, and P. Cuesta. 1996. Effect of lactic starter cultures on the organic acid composition of milk and cheese during ripening-analysis by HPLC. J. Appl. Microbiol. 80:570-576.

Heimhuber, B., and K. Hermann. 1990. Benzoe-, phenylessig-, 3-Phernylpropan- und Zimtsaure sowie Benzoylglucosen in einigen Obstund Fruchtgemusearten. Dtsch. Lebensmitt. Rundsch. 86:205-209.

Horak, V., P. Cuhra, J. Dolejskova, F. Louda, H. Dragounavo, and P. Neuhybel. 1996. Hippuric and benzoic acid in milk and dairy products. Czech J. Anim. Sci. 41:277-279.

MFDS. 2014. Food Additives Codex. Ministry of Food and Drug Safety, Seoul, South Korea.

Miller, E. J. C., and J. N. Miller. 1988. Statistics for Analytical Chemistry. 3rd ed. Ellis Horwood PTR Prentice Hall, New York, NY.

Mroueh, M., D. Issa, J. Khawand, B. Haraty, A. Malek, Z. Kassaify, and I. Toufeili. 2008. Levels of benzoic and sorbic acid preservatives in commercially produced yoghurt in Lebanon. J. Food Agric. Environ. 6:62-66.

Nagayama, T., M. Nishijima, K. Yasuda, K. Saito, H. Kamimura, A. Ibe, H. Ushiyama, M. Nagayama, and Y. Naoi. 1983. Benzoic acid in fruits and fruit products. Shokuhin Eiseigaku Zasshi 24:416-422.

Nagayama, T., M. Nishijima, K. Yasuda, K. Saito, H. Kamimura, A. Ibe, H. Ushiyama, Y. Naoi, and T. Nishima. 1986. Benzoic acid in agricultural food products and processed foods. Shokuhin Eiseigaku Zasshi 27:316-325.

Nishimoto, T., M. Uyera, S. Taue, and I. Takebayashi. 1968. Bacterial formation of benzoic acid in milk. Shokuhin Eiseigaku Zasshi 9:58-59. 
Nishimoto, T., M. Uyeta, and S. Taue. 1969. The precursor of benzoic acid in fermented milk. Shokuhin Eiseigaku Zasshi 10:410-413.

Park, S. Y., N. Han, S. Y. Kim, M. Y. Yoo, H. D. Paik, and S. D. Lim. 2016. Evaluation of natural food preservatives in domestic and imported cheese. Korean J. Food Sci. Anim. Resour. 36:531-537.

Pereira, A. S., K. D. Kenney, M. S. Chhen, J. E. Hall, J. J Eron, R. R. Tidwell, and J. A. Dunn. 2000. Simultaneous determination of lamivudine and zidovudine concentrations in human seminal plasma using high performance liquid chromatography and tandem mass spectrometry. J. Chromatogr. B Biomed. Sci. Appl. 742:173-183.

Rusul, G., and E. H. Marth. 1988. Growth and aflatoxin production by Aspergillus parasiticus in a medium at different $\mathrm{pH}$ values and with or without pimaricin. Z. Lebensm. Unters. Forsch. 187:436-439.

Sieber, R., U. Butikofer, and J. O. Bosset. 1995. Benzoic acid as a natural compound in cultured dairy products and cheese. Int. Dairy J. 5:227-246.
Splittstoesser, D. F., M. R. McLellan, and J. J. Churey. 1996. Heat resistance of Eschericha coli O157:H7 in apple juice. J. Food Prot. $59: 226-229$.

Tavaria, F. K., S. Dahl, F. J. Carbollo, and F. X. Malcata. 2002. Amino acid carabolism and generation of volatiles by lactic acid bacteria. J. Dairy Sci. 85:2462-2470.

Tfouni, S. A. V., and M. C. F. Toledo. 2002. Determination of benzoic and sorbic acids in Brazilian food. Food Cont. 13:117-123.

Thompson, D. P. 1997. Effect of phenolic compounds on mycelial growth of Fusarium and Penicillium species. J. Food Prot. 10:1262-1264.

Urbiene, S., and D. Leskauskaite. 2006. Formation of some organic acids during fermentation of milk. Pol. J. Food Nutr. Sci. 3:277-281.

WHO. 2000. Benzoic acid and sodium benzoate. Concise International Chemical Assessment Document 26. World Health Organization (WHO), Geneva, Switzerland. 